\title{
PEMANFAATAN LIMBAH JERAMI SEBAGAI MEDIA PERTUMBUHAN JAMUR TIRAM
}

\author{
Sri Wahyuni ${ }^{1}$,Bambang Hermanto ${ }^{2}$ \\ Fakultas Pertanian Universitas Muslim Nusantara \\ Kampus A: Jl.Garu II No.93 \\ costusyuni@yahoo.co.id
}

\begin{abstract}
ABSTRAK
Limbah adalah segala sesuatu yang sudah tidak terpakai lagi sebagai barang produksi maupun konsumsi, yang jika langsung dibuang ke lingkungan tanpa pengolahan terlebih dahulu dapat menjadi beban bagi lingkungan. Jenis limbah yaang ada di areal pertanian diantaranya adalah jerami.Limbah pertanian ini masih mengandung zat-zat yang bisa dimanfaatkan untuk meningkatkan nilai guna limbah tersebut. Salah satu usaha untuk mengatasi masalah tersebut adalah memanfaatkan limbah, sehingga mempunyai nilai ekonomi tinggi, seperti mengubah limbah menjadi media tumbuh jamur,Pada umumnya substrat atau media tanam yang digunakan dalam budidaya jamur tiram adalah serbuk gergaji kayu sengon karena mengandung selulosa, hemiselulosa dan lignin yang dapat mempercepat tumbuh jamur. Konsekuensi akan timbul masalah apabila serbuk gergaji sulit diperoleh, kalaupun ada harganya cukup mahal. Hal ini terjadi karena potensi hutan saat ini berkurang dan dibatasi. Selain itu pemanfaatan serbuk gergaji juga untuk pembuatan arang aktif, briket arang, campuran pembuatan batako dan lain-lain. Upaya untuk mengantisipasi hal tersebut perlu dicari substrat alternatif yang tersedia dan mudah didapat. Alternatif bahan yang bisa digunakan untuk menggantikan serbuk gergaji kayu salah satunya adalah berbagai limbah pertanian. Tujuan jangka panjang pengabdian ini adalah untuk menambah wawasan pengetahuan serta pelatihan budidaya jamur tiram di desa Doulu Kecamatan Berastagi. Dalam Penelitian ini menggunakan dua tahap antara lain tahap diskusi, meliputi pengenalan jamur tiram dan substansi material media pertumbuhan janur tiram dan tahap pelatihan meliputi tahapan untuk budidaya jamur tiram.
\end{abstract}

Kata Kunci : Limbah Jerami, Jamur Tiram

\begin{abstract}
Waste is everything that is no longer used as a production or consumption goods, which if directly discharged into the environment without processing in advance can be a burden for the environment. Types of sewage in the agricultural area include straw. This agricultural waste still contains substances that can be utilized to increase the value of waste. One effort to overcome the problem is to utilize the waste, so it has high economic value, such as converting waste into mushroom growing media, In general, substrate or planting media used in the cultivation of oyster mushrooms is sawdust sengon wood because it contains cellulose, hemicellulose and lignin can accelerate the growth of fungus. The consequences will arise if the sawdust is difficult to obtain, even if the price is quite expensive. This is because the potential for forests is currently reduced and restricted. In addition, the utilization of sawdust is also for the manufacture of activated charcoal, charcoal briquettes, mixed brick making and others. Efforts to anticipate
\end{abstract}


this need to look for available and readily available substrate substrates. Alternative materials that can be used to replace wood sawdust one of them is a variety of agricultural waste. The purpose of this service dedication is to increase the knowledge knowledge and training of oyster mushroom cultivation in the village of Doulu Kecamatan Berastagi. In this study, the two stages between the stages of discussion, including the introduction of oyster mushrooms and substance material growth media oyster leaf and training phase includes stages for oyster mushroom cultivation.

Keywords: Waste Straw, Oyster Mushroom

\section{Pendahuluan}

\subsection{Latar Belakang}

Mata pencaharian sebagai buruh tani merupakan profesi yang sangat sulit untuk masa sekarang, jika tidak diimbangi dengan usaha yang lain untuk meningkatkan taraf hidup keluarga. Salah satu permasalahan yang kita lihat di pertanian saja, yaitu dari segi pupuk untuk mengolah areal pertanian saja sudah sangat minim, meskipun hal tersebut sudah di subsidi oleh pemerintah akan tetapi petani masih mengalami masalah harga untuk pupuk yang meonjak tinggi diakibatkan subsidi pupuk oleh pemerintah jumlahnya sangat terbatas. Disisi lain, meningkatnya produktivitas berbagai jenis tanaman pertanian juga menjadi masalah yang lain diantaranya meningkatnya limbah pertanian, jika tidak dikelola dengan baik. Limbah adalah segala sesuatu yang sudah tidak terpakai lagi sebagai barang produksi maupun konsumsi, yang jika langsung dibuang ke lingkungan tanpa pengolahan terlebih dahulu dapat menjadi beban bagi lingkungan. Jenis limbah yaang ada di areal pertanian diantaranya adalah jerami.

Limbah pertanian ini masih mengandung zat-zat yang bisa dimanfaatkan untuk meningkatkan nilai guna limbah tersebut. Salah satu usaha untuk mengatasi masalah tersebut adalah memanfaatkan limbah, sehingga mempunyai nilai ekonomi tinggi, seperti mengubah limbah menjadi media tumbuh jamur, karena masih mengandung selulosa. Limbah perkebunan dan pertanian antara lain berupa tandan kosong kelapa sawit, jerami padi,batang jagung, tongkol jagung dan lain-lain.

Kandungan nutrisi dalam 100 gam jerami padi terdiri dari selulosa sebanyak 29,63\%, dengan kandungan hemiselulosa sebanyak $17,11 \%$ dan lignin sebanyak $12,17 \%$ . Jerami padi biasanya dibakar atau dimanfaatkan sebagai pakan ternak. Jerami padi mempunyai serat yang tinggi tetapi proteinnya rendah. Jerami berfungsi sebagai substrat tempat menempelnya miselium dan sumber nutrisi, terutama karbon .

Menurut hasil penelitian, bahwa media tanam jerami padi memberikan pengaruh terhadap pertumbuhan dan hasil dari jamur merang yang lebih baik daripada media tanam ampas kelapa sawit. Perbedaan terlihat nyata pada panjang buah, diameter badan buah, berat badan dan jumlah badan buah pada kedua media tersebut. Pada media tanam jerami, berat badan buah jamur merang yang dihasilkan yaitu 176,35 gram, sedangkan untuk media tanam ampas kelapa sawit menghasilkan berat badan buah jamur merang yaitu 162,68 gram. 
Pada umumnya substrat atau media tanam yang digunakan dalam budidaya jamur tiram adalah serbuk gergaji kayu sengon karena mengandung selulosa, hemiselulosa dan lignin yang dapat mempercepat tumbuh jamur. Konsekuensi akan timbul masalah apabila serbuk gergaji sulit diperoleh, kalaupun ada harganya cukup mahal. Hal ini terjadi karena potensi hutan saat ini berkurang dan dibatasi. Selain itu pemanfaatan serbuk gergaji juga untuk pembuatan arang aktif, briket arang, campuran pembuatan batako dan lain-lain. Upaya untuk mengantisipasi hal tersebut perlu dicari substrat alternatif yang tersedia dan mudah didapat. Alternatif bahan yang bisa digunakan untuk menggantikan serbuk gergaji kayu salah satunya adalah berbagai limbah pertanian.

Dari paparan diatas,melihat situasi yang ada di negara kita ini, penulis bermaksud melaksanakan program pengabdian masyarakat di desa doulu kecamatan berastagi dimana potensi yang sangat banyak area pertaniannya, maka sudah selayaknyalah kita memikirkan pemanfaatan hasil limbahnya, yaitu jerami.

\subsection{Tujuan}

1. Menambah wawasan petani tentang pemanfaatan limbah jerami sebagai media pertumbuhan jamur tiram.

2. Menambah pengetahuan tentang budidaya jamur tiram ke masyarakat desa Doulu Kecamatan Berastagi

3. Menambah peluang berkewirausahaan masyarakat desa Doulu Kecamatan Berastagi.

\subsection{Pendekatan Pemecahan \\ Masalah}

Apakah limbah pertanian yaitu jerami dapat menjadi peluang usaha lain bagi para petani di desa doulu untuk menambah rata-rata mata pencaharian di desa tersebut ?

\section{Metode}

Metode pelaksanaan kegiatan pengabdian kepada masyarakat dilakukan dengan cara sebagai berikut :

1. Pembuatan media tanam dilakukan dengan memotong jerami menjadi berukuran $1-2 \mathrm{~cm}$.

2. Rendam jeraminya selama semalaman. Setelah itu, ditiriskan airnya sebelum ditambahkan dedak $10 \%$ dan kapur 1\% sebagai zat hara pertumbuhan jamur.

3. Semua bahan diaduk rata dan campuran bahan tadi dimasukkan ke dalam plastik yang tahan panas hingga terisi $2 / 3$ bagian.

4. Baru kemudian dipadatkan (dipukul-pukul dengan botol kaca).

5. Setelah cukup padat, leher plastik bagian atas dimasukkan pipa paralon dan dibagian tengah media subtrat diberi lubang dan ditancapkan tips.

6. Selanjutnya ditutupi dengan kapas lalu media substrat dilapisi dengan kertas dan diikat dengan karet.

7. Media tersebut disterilisasi pada $121^{\circ} \mathrm{C}$ selama 20 menit di dalam autoklaf untuk memastikan bahwa tidak ada kontaminan yang tumbuh yang mungkin akan mengganggu pertumbuhan jamur.

8. Setelah steril, media substrat dibuka secara aseptis, lalu tips di tengah-tengah media dan kapas diambil dengan pinset steril. 
9. Lubang yang terbentuk diisi dengan bibit jamur tiram yang ditumbuhkan pada biji sorgum pada botol (aseptis).

10. Lalu media ditutup kapas lagi dan dibungkus dengan kertas.Media substrat diinkubasi pada suhu ruang selama beberapa minggu hingga tumbuh miselium.

11. Setelah tumbuh miselium, kapas pada media dibuang dan media dibiarkan terbuka.

12. Semprotkan air setiap hari pada tempat pertumbuhan jamur agar kondisi sekitar lembab dan mendukung pertumbuhannya.

13. Tubuh buah jamur akan tumbuh secara perlahan-lahan ketika media lembab dalam waktu sekitar 1 bulan lebih.

14. Tubuh buah yang sudah cukup besar diambil dan ditimbang untuk diamati pertumbuhannya setiap minggu.

\section{Hasil dan Pembahasan}

\section{Pelaksanaan kegiatan}

Pengabdian kepada Masyarakat dengan Judul "Pemanfaatan Limbah Jerami sebagai media pertumbuhan jamur tiram". dilaksanakan di Desa Doulu Kecamatan Berastagi telah dilaksanakan dengan melakukan kegiatan yang telah tercapai sebagai berikut :

1. Melakukan sosialisasi kepada mitra tentang kegiatan pengabdian kepada masyarakat tentang program ini.

2. Memberikan informasi tentang pemanfaatan limbah jerami sebagai media tanam jamur tiram.

3. Memberikan informasi tentang karakteristik jamur tiram (syarat hidup,suhu yang sesuai pertumbuhannya, $\mathrm{PH}$,
Kelembaban,cahaya,

ketinggian tempat, nutrisi, pengendalian hama dan penyakit dan udara) yang sesuai untuk pertumbuhan jamur tiram.

4. Pengenalan Substansi/ bahanbahan material (jerami, dedak, kapur,gypsum) yang dibutuhkan untuk membuat media tanam jamur tiram.

5. Memberikan pelatihan tentang praktek budidaya jamur tiram dengan pemanfaatan limbah jerami.

\section{Kesimpulan}

Kegiatan pengabdian kepada masyarakat sudah dilakukan sampai dengan tahapan pemberian pengetahuan dan pelatihan pemanfaatan limbah jerami untuk pembuatan media pertumbuhan jamur tiram. Selanjutnya akan diberikan pengetahuan, pelatihan budidaya jamur tiram di lapangan serta cara pengolahan makanan dari jamur tiram sampai tahap proses pemasaran produk jamur tiram.

\section{Daftar Pustaka}

Draski H dan Ernita. 2013.Pengaruh Jenis Mediadan Komposisi FosforTerhadap

Pertumbuhan Jamur Tiram Putih (Pleurotus ostreatus).Jurnal dinamika pertanian. vol xxviii (3): 203-210.

Gandjar I, Wellyzar S, Oetari A. 2006. Mikologi:Dasardan Terapan. Jakarta: Yayasan Obor Indonesia.hal 238.

Hariadi N, Setyobudi L, NihayatiE. 2013. StudiPertumbuhandan Hasil Produksi Jamur Tiram Putih(Pleorotus ostreatus) pada Media Tumbuh Jerami 

$\begin{array}{lr}\text { Padidan } & \text { Serbuk } \\ \text { Gergaji.Jurnal } & \text { produksi } \\ \text { tanaman. vol 1 (1):47-53. }\end{array}$

Lakitan B. 2011. Dasar-Dasar Fisiologi Tumbuhan. Jakarta:Rajawali Pers.hal99. Maulana E.2012.PanenJamur Tiap Musim. Lampung:Lily Publisher. hal 150-175.

Meinanda I. 2013. PanenCepat Budidaya Jamur. Bandung:Padi. hal 50.
Munawar A.2011.Kesuburan tanah dan nutrisi tanaman. Bogor:IPB press.hal 30.

Piryadi T.2013.Bisnis Jamur Tiram. Jakarta: PT Agro Media Pustaka.hal 27.

Sumiati E, Suryaningsih E, Puspitasari.2006. Perbaikan Produksi Jamur Tiram Pleurotus ostreatusStrain Florida dengan Modifikasi Bahan Baku Utama Substrat. J. Hort.vol16 (2):96-107. 